\title{
Silviculture-driven vegetation change in a European temperate deciduous forest
}

\author{
Guillaume DECOCQ ${ }^{\mathrm{a} *}$, Michaël AUBERT ${ }^{\mathrm{b}}$, Frédéric DUPONT ${ }^{\mathrm{c}}$, Jacques BARDAT $^{\mathrm{a}}$, \\ Annie WATTEZ-Franger ${ }^{\mathrm{a}}$, Robert SAGUEZ ${ }^{\mathrm{a}}$, Bruno DE FOUCAULT ${ }^{\mathrm{c}}$, Didier ALARD ${ }^{\mathrm{b}, \mathrm{e}}$, \\ Annick DELELIS-DUSOLLIER ${ }^{\mathrm{c}}$ \\ a Département de Botanique, Université de Picardie Jules Verne, 1 rue des Louvels, 80037 Amiens Cedex, France \\ b Laboratoire d'Écologie, UPRES-EA 1293, Université de Rouen, 76821 Mont Saint-Aignan Cedex, France \\ c Département de Botanique, Université de Lille 2, 3 rue du Professeur Laguesse, BP 83, 59006 Lille Cedex, France \\ d Institut d'Écologie et de Gestion de la Biodiversité, Service du Patrimoine naturel, Muséum national d'Histoire Naturelle, \\ 57 rue Cuvier, 75231 Paris Cedex 5, France \\ e INRA, Centre de Toulouse, UMR 1201 DYNAFOR, BP 27, 31326 Castanet-Tolosan Cedex, France
}

(Received 17 June 2004; accepted 17 December 2004)

\begin{abstract}
Forest management consists in anthropogenic disturbances that are able to modulate ecological features, resource availability and successional patterns. Plant communities are thus expected to react differently to contrasted silvicultural systems. We compared plant species composition between stands submitted to a traditional management since many centuries (i.e. coppice-with-standards treatment, stands intensively but infrequently disturbed) and stands recently converted into a selective cutting system (stands moderately but frequently disturbed), over uniform edaphic and topographic conditions. We found significant differences in species composition between both systems. Despite a strong shift in species composition among different stages of the coppice cycle, coppice-with-standards stands supported the highest number of true forest species. Selectively-cut stands were more homogeneous and characterized by ruderal "generalist" species. These fast changes in vegetation composition were related to differences in a group of factors that are directly or indirectly linked to the silvicultureassociated disturbance regime, including soil moisture, soil fertility, forest microclimate, light and game predation. We conclude that the conversion of a silvicultural system which has patterned plant communities since many centuries, induces early major changes in vegetation composition. The most negatively impacted species are the so-called "true forest species" that may be better labelled "coppice-woodland species".
\end{abstract}

disturbance / microclimate / forest management / plant diversity / true forest species

Résumé - Changements de la composition floristique induits par la sylviculture dans une forêt tempérée caducifoliée européenne. La sylviculture est une perturbation anthropogène capable de moduler les facteurs environnementaux, la disponibilité des ressources et la dynamique forestière. La végétation spontanée est donc susceptible de réagir différemment à des systèmes sylviculturaux contrastés. La composition floristique de parcelles forestières traitées en taillis-sous-futaie depuis plusieurs siècles a été comparée à celle de parcelles récemment converties en futaie irrégulière coupée « pied-à-pied », en conditions édaphique et topographique uniformes. Malgré des différences importantes en fonction du temps écoulé depuis la dernière coupe, la partie de la forêt traitée en taillis-sous-futaie hébergeait un nombre plus important d'espèces forestières. Les parcelles en futaie irrégulière étaient plus homogènes et caractérisées par des espèces rudérales « généralistes ». Ces changements précoces de la composition spécifique ont pu être reliés à des modifications du contexte environnemental, directement ou indirectement induites par la sylviculture, incluant l'humidité et la fertilité du sol, le microclimat forestier, la lumière et la prédation par le chevreuil. La conversion d'un type sylvicultural, qui a façonné les communautés végétales durant des siècles, induit donc rapidement des changements majeurs dans la composition floristique. Les espèces les plus affectées sont les espèces considérées comme forestières, qu'il conviendrait plutôt d'appeler « espèces des taillis ».

perturbation / microclimat / sylviculture / biodiversité végétale / espèces forestières vraies / taillis-sous-futaie

\section{INTRODUCTION}

The current theory of species richness and community structure considers disturbance as a key concept $[7,10]$. Within this framework, forest management may be considered as a complex of anthropogenic disturbances [57, 69] able to modulate ecological features, self-regulating processes (e.g. assembly rules), succession patterns, resources availability and productivity $[21,32,38,47,48]$. As a consequence, the silvicultureassociated disturbance regime play an important role in structuring plant communities. During the last decades, disturbance theory has received growing attention from ecologists and

\footnotetext{
*Corresponding author: guillaume.decocq@u-picardie.fr
} 
environment managers. In forestry, it has played an important role in the emergence of new harvesting practices that are expected to be closer to the natural forest dynamics than the "traditional" treatment. New silvicultural systems have emerged, based on the assumption that diversity patterns and ecological processes are more likely to persist if disturbances occurring through management mimic the patterns and processes of natural disturbances [27, 30, 51]. Nevertheless, in European temperate forests natural disturbance regimes have become an exception since most forests have been managed, often since the Roman times, according to systems close to coppice-withstandards or single coppice, a few being high forests harvested tree-by-tree $[39,55]$. As a consequence, forest management is often considered as the main control on forest vegetation [4, 5, $29,70,71]$ and long-term effects on forest composition are expected, since the current forest flora may be adapted to "fit" the human-induced disturbance regime imposed for nearly two millennia [20]. A dramatic change in silvicultural practices may thus induce major changes in vegetation composition and forest succession. However little is known about the long-term effects of these "close-to-nature" silvicultural systems. Most previous studies dealing with selective cutting systems were conducted in northern America, where forest history is radically different compared to European forests [6, 12, 29, 31, 35, 66]. In Europe, comparative surveys between "traditional" treatments and "modern silviculture" mainly involve evenaged plantations for which the disturbance regime strongly differs from the one characterizing selective cutting systems [2, $5,64]$. It is thus important to gain more basic informations about the interactions between silvicultural treatments and changes in both vegetation patterns and ecological features. In this study, we test the hypothesis that a shift of silvicultural system in a temperate deciduous forest with a long history of "traditional" management may induce significant early-changes in vegetation patterns and thus in forest dynamics. Our research questions were (1) does species composition vary as a function of the type of silviculture over uniform soil, topography and climate conditions, and (2) could these variations be explained by changes in the disturbance regime, forest structure or ecological features? For this purpose, we surveyed vegetation in a temperate deciduous forest submitted to a traditional coppice-withstandards treatment for many centuries, which has been partly converted into a "close-to-nature" selective cutting system since two decades.

\section{METHODS}

\subsection{Study area}

The study was conducted in the Le Nouvion forest (department Aisne, France; $50^{\circ} 00^{\prime} \mathrm{N}, 3^{\circ} 50^{\prime} \mathrm{E}, 180-220 \mathrm{~m}$ altitude), which covers $\sim 4000$ ha. It is a former royal forest for which forest continuity has never been interrupted since Antiquity. The climate is of suboceanic type with an average annual temperature of $9.1^{\circ} \mathrm{C}$ and precipitation of $950 \mathrm{~mm}$. The geological substrate consists of cretaceous marls and clays (Turonian) largely covered by a quaternary loess layer of a few meters deep with a high clay content. Soils are leached brown earths with moderate internal drainage (Luvisol according to the FAO classification). The vegetation consists of a temperate deciduous forest affiliated to the Querco roboris - Carpinetum betuli Tüxen 1930 phy- tosociological association [16]. The dominant tree species in the area is oak, Quercus robur L., which is associated with hornbeam (Carpinus betulus L.), ash (Fraxinus excelsior L.) and sycamore (Acer pseudoplatanus L.). The entire forest was managed as hornbeam coppicewith-oak standards (CWS) from the mid-17th to the late 20th century. Since the end of the 1970s, new silvicultural systems were developed and former CWS stands were progressively converted:

- Part of the forest was submitted to a system close to the former CWS (modern CWS), which aims at a regular evenaged structure of the standards while coppice wood is maintained. In this system, commercial felling occurs every 30 years, including the extraction of the whole coppice timber and three quarters $\left(\sim 200 \mathrm{~m}^{3} \cdot \mathrm{ha}^{-1}\right)$ of the standards. Harvested products are hauled out by heavy vehicles which always use the same trails. This system is currently conducted by the French Office National des Forêts;

- Another part of the forest has been converted into a selective cutting system (SC), conducted by a private company. In SC, precommercial thinnings are conducted every 4 years (partial extraction of coppice wood: shrub species and unsuitable tree species at $\sim 23 \mathrm{~m}^{3} \cdot \mathrm{ha}^{-1}$ ) and commercial felling every 8 years (selective cutting of individual mature trees at $\sim 10 \mathrm{~m}^{3} \cdot \mathrm{ha}^{-1}$ ). Harvested products are hauled out by heavy vehicles which drive through forest stands, frequently using different paths.

These two silvicultural systems provide similar extraction rates $\left(\sim 7 \mathrm{~m}^{3} \cdot \mathrm{ha}^{-1} \cdot \mathrm{yr}^{-1}\right.$ on average) and basal area (mean \pm standard deviation [extremes]: $17.8 \pm 7.0$ [3.0-32.7] $\mathrm{m}^{2} . \mathrm{ha}^{-1}$ for CWS and $16.2 \pm$ 6.9 [4.0-33.2] $\mathrm{m}^{2} \cdot \mathrm{ha}^{-1}$ for SC), but strongly differ in their disturbance regimes (intensity, frequency and spatial extent of harvesting) and vertical forest structure.

Browsing is mainly due to roe deer (Capreolus capreolus L.) which is the only ungulate present on the site. Population density reaches 30 individuals per 100 hectares on average, with large variations depending on the part of the forest considered (from 8 to 40 individuals per $100 \mathrm{ha}$ ).

\subsection{Sample design and data collection}

Our sampling procedure was designed to reduce environmental variation caused by site variability. For this purpose all the forest stands included in this study were located in similar abiotic conditions, characterised by the same substrate (loess with thickness exceeding $5 \mathrm{~m}$ ) and topographic position (plateau), all the soils being haplic luvisol according to the World reference base. As we compared vegetation patterns under different silvicultural systems within similar abiotic conditions, we should be able to identify relationships between plant community composition and silviculture. The sample design is shown in Figure 1. We sampled a total of 115 forest stands distributed into 2 groups and 5 subgroups:

(1) CWS stands, including (1a) aging CWS stands $(n=10)$, which were located in parts of the forest which have escaped any management and remained unexploited since at least 50 years; (1b) postlogged CWS stands $(n=10)$, which were harvested during the last 4 years; (1c) mature CWS stands $(n=25)$, aged from 24 to 30 years and which would be soon exploited;

(2) SC stands, including (2a) exclosed SC stands $(n=50)$, and (2b) enclosed SC stands $(n=20)$, which were fenced since 8 years to protect young trees from game damage.

Within each included stand a temporary $400 \mathrm{~m}^{2}$ quadrat was randomly placed at a minimum of $10 \mathrm{~m}$ away from forest roads, clearings, etc., to minimise edge effects. Vegetation surveys and other measurements were conducted during periods of peak vegetation cover (MayAugust) from 1999 to 2001. For each quadrat a phytosociological relevé was compiled, restricted to vascular plant species. Woody species were recorded in one or more vegetation layer, defined as follow: tree layer ( $>8 \mathrm{~m}$; A), shrub layer $(2-8 \mathrm{~m} ; \mathrm{s})$, undershrub layer $(0.5-$ $2 \mathrm{~m}$; us) and herb layer $(<0.5 \mathrm{~m} ; \mathrm{H})$. Cover-abundance of plant species was visually estimated on the field as the vertically projected area 


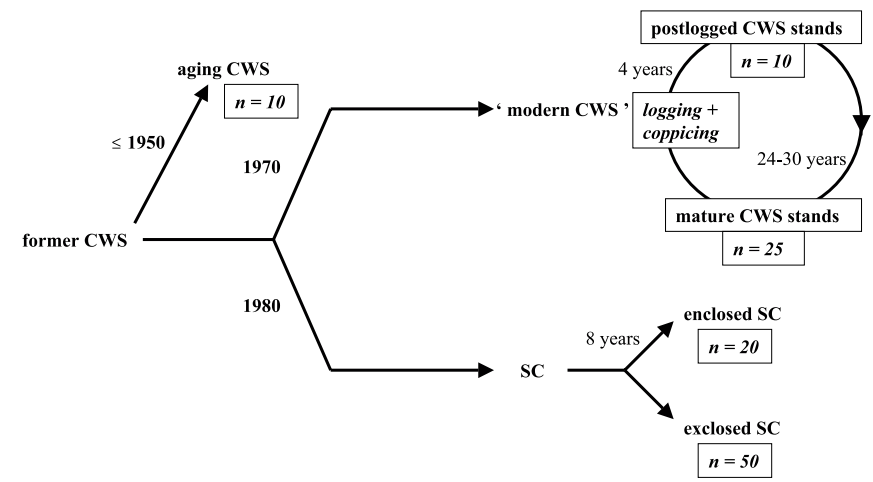

Figure 1. Sample design among the different sylvicultural systems (boxes contain the number of stands sampled). CWS: Coppice-withstandards, SC: Selective cutting.

using the Braun-Blanquet scale [9]. Nomenclature follows Lambinon et al. [40]. Total cover per layer was estimated as a percentage of the total plot area.

\subsection{Data analysis}

A floristic data matrix was first constructed, including the 115 phytosociological relevés. Cover-abundance indices were transformed according to the ordinal scale of Van der Maarel [69] prior to numerical analysis. Species occurring in less than $5 \%$ were deleted in analyses.

Firstly, we investigated between-stand differences in community composition. Two steps were followed: we first compared the two silvicultural systems (CWS versus SC) and then, we compared the 5 subgroups of stands defined above (postlogged CWS, mature CWS, aging CWS, exclosed SC, enclosed SC). We used MRPP (Multiresponse permutation procedure [50]) to test for compositional differences between stand types. The quantitative version of Sørensen's index was used as a measure of distance. MRPP provides a statistic T that is the difference between the observed and expected weighted mean within-groups distance $\delta$ divided by the square root of the variance in expected $\delta$. The more negative is T, the stronger the separation. T is associated with a chance-corrected within-group agreement A that describes the "effect size", and a $p$-value which indicates the likehood of getting a $\delta$ equal or smaller than that observed by chance [45]. The differences among groups and sub-groups were then described using Dufrêne and Legendre's indicator species analysis (ISA) [24]. Monte Carlo test of significance of observed maximum indicator value for each species was used, based on 1000 randomizations $(p<0.05)$. Indicator species groups were finally interpretated using the autoecological backgrounds of species provided by Grime et al. [33], Rameau et al. [58] and Ellenberg et al. [25], and the checklist of Hermy et al. [37] for "ancient forest species". Both MRPP and ISA were performed using PC-Ord ${ }^{\circledR}$ v. 5 software [46].

Secondly, ordination methods were used to detect relations among groups and between groups and potential environmental gradients. To avoid distortion of the true gradient structure of the data set, we followed the recommendations of Økland [55]. Detrended correspondence analysis (DCA) was first used to find gradients in species composition as hypothetical environmental variables which best fit species'abundance to an explicit model of species'responses to environmental gradients. Nonmetric multidimensional scaling (NMS) was then implemented to configure "relevés" in an ordination space with a fixed number of dimensions and to optimize the rank-order corre- spondence between relevés distances in the ordination diagram and between relevés floristic dissimilarities. Both methods were run using PC-Ord ${ }^{\circledR}$ software [46]. DCA was run with standard options for detrending by segments, non-linear rescaling of axes and downweighting of rare species. NMS used the quantative form of Sørensen's index as a measure of between-plot similarity. A three-dimensional solution was obtained with a maximum of 200 iterations and 30 runs with randomized data. Axes of the DCA and NMS ordinations were compared by calculating pairwise Spearman rank correlation coefficients using Statview ${ }^{\circledR}$ software. Strong correlations were interpreted as favouring the main data gradient structure.

Where the two methods produced congruent axes, ecological interpretation was restricted to DCA axes [55]. Environmental controls on vegetation were deduced from the Ellenberg indicator values for light $(\mathrm{L})$, soil moisture $(\mathrm{F})$, soil nutrient $(\mathrm{N})$, soil reaction $(\mathrm{R})$ and continentality $(\mathrm{K})[25]$ and expressed as weighted averages after transformation of cover-abundance values as suggested by Van der Maarel [68]. This system offers an alternative to direct field measurements for defining site characteristics. Spearman rank correlations $(p<0.05)$ were then calculated between ordination scores obtained and Ellenberg indicator values using Statview ${ }^{\circledR}$ software.

\section{RESULTS}

MRPP indicated that differences in species composition between the 2 groups and among the 5 sub-groups were lower than the heterogeneity expected from random grouping $(\mathrm{T}=$ -47.097; $\mathrm{A}=0.089 ; p<0.0001$ and $\mathrm{T}=-43.534 ; \mathrm{A}=0.170$; $p<0.0001$ respectively). Results of the ISA are reported in Table I. Most woody species were constant among the stands assessed, as well as several herb species which mainly consisted of grass and fern species. CWS stands were characterized by mid-successional tree species (e.g. Fraxinus excelsior, Prunus avium), climbers (e.g. Hedera helix, Lonicera periclymenum), stress-tolerant ruderal herbs (e.g. Hyacinthoides nonscripta, Arum maculatum) and "ancient forest species" (e.g. Anemone nemorosa, Oxalis acetosella). These species tended to lack in SC stands, which were rather characterized by shrubby individuals of early successional light-demanding tree species (e.g. Alnus glutinosa, Betula spp.), ferns (e.g. Dryopteris spp., Athyrium filix-femina) and grasses (e.g. Milium effusum, Carex remota). It is noteworthy that SC stands shared some floristic similarities with postlogged CWS stands, consisting of light-demanding grasses (e.g. Agrostis canina, Holcus mollis) or forbs (e.g. Senecio ovatus, Rubus idaeus), and woody saplings (e.g. Quercus robur).

Within the CWS group, the three subgroups strongly differed by their indicator species. As expected, postlogged stands supported a lot of early-successional species. Mature CWS stands were mainly characterized by several mid-successional woody species (e.g. Carpinus betulus, Sorbus aucuparia). Finally, aging stands were strongly differenciated thanks to several herb species which were almost restricted to these stands. They were either "ancient forest species" (e.g. Anemone nemorosa, Paris quadrifolia, Viola reichenbachiana) or species of moist soils (e.g. Cardamine pratensis, Filipendula ulmaria, Valeriana repens). It should be noted therefore that the latters usually did not flowerish. Aging stands were also characterized by the lack of woody saplings for almost all the tree and shrub species. 
Table I. Species recorded in the whole survey, distributed among the five sub-groups of stands according to the results of Indicator species analysis.

\begin{tabular}{|c|c|c|c|c|c|c|}
\hline & Aging CWS & Mature CWS & Postlogged CWS & Enclosed SC & Exclosed SC & $p$ \\
\hline Number of stands & 10 & 25 & 10 & 20 & 50 & \\
\hline Hyacinthoides non-scripta & & 85 & & & & $* *$ \\
\hline Polygonatum multiflorum & & 72 & & & & $* *$ \\
\hline Oxalis acetosella & & 63 & & & & $* *$ \\
\hline Corylus avellana s & & 62 & & & & $* *$ \\
\hline Fraxinus excelsior A & & 61 & & & & $* *$ \\
\hline Lamium galeobdolon & & 61 & & & & $* *$ \\
\hline Carpinus betulus $A$ & & 52 & & & & $* *$ \\
\hline Lonicera periclymenum $H$ & & 43 & & & & $* *$ \\
\hline Carex sylvatica & & 39 & & & & $* *$ \\
\hline Salix caprea A & & 27 & & & & $* *$ \\
\hline Viburnum opulus $H$ & & 20 & & & & $* *$ \\
\hline Lonicera periclymenum us & & 18 & & & & $* *$ \\
\hline Prunus avium A & & 16 & & & & $* *$ \\
\hline Corylus avellana A & 23 & 10 & 0 & 3 & 0 & * \\
\hline Lonicera periclymenum $s$ & 17 & 15 & 3 & 0 & 0 & * \\
\hline Sorbus aucuparia us & 0 & 15 & 42 & 2 & 0 & $* *$ \\
\hline Carpinus betulus $H$ & 2 & 28 & 28 & 6 & 17 & $* *$ \\
\hline Sorbus aucuparia $H$ & 0 & 43 & 23 & 2 & 2 & $* *$ \\
\hline Fraxinus excelsior $H$ & 5 & 20 & 30 & 1 & 11 & * \\
\hline Anemone nemorosa & 97 & 0 & 0 & 0 & 0 & ** \\
\hline Paris quadrifolia & 90 & 0 & 0 & 0 & 0 & ** \\
\hline Ranunculus ficaria & 83 & 0 & 6 & 0 & 0 & ** \\
\hline Cardamine pratensis & 77 & 0 & 1 & 0 & 0 & $* *$ \\
\hline Valeriana repens & 70 & 0 & 0 & 0 & 0 & $* *$ \\
\hline Arum maculatum & 60 & 0 & 0 & 0 & 0 & $* *$ \\
\hline Viola reichenbachiana & 59 & 2 & 6 & 0 & 0 & $* *$ \\
\hline Filipendula ulmaria & 50 & 0 & 0 & 0 & 0 & $* *$ \\
\hline Hedera helix $H$ & 0 & 55 & 10 & 0 & 0 & $* *$ \\
\hline Sorbus aucuparia s & 0 & 49 & 1 & 0 & 0 & $* *$ \\
\hline Sorbus aucuparia A & 0 & 46 & 0 & 0 & 0 & ** \\
\hline Betula alba A & 4 & 30 & 4 & 15 & 4 & * \\
\hline Carpinus betulus s & 18 & 30 & 0 & 24 & 7 & * \\
\hline Hedera helix s & 0 & 23 & 2 & 0 & 0 & ** \\
\hline Crataegus monogyna s & 0 & 22 & 0 & 0 & 0 & $* *$ \\
\hline Hedera helix A & 0 & 18 & 3 & 0 & 0 & * \\
\hline Juncus effusus & 0 & 0 & 55 & 9 & 19 & $* *$ \\
\hline Stellaria holostea & 0 & 0 & 55 & 0 & 4 & $* *$ \\
\hline Silene dioica & 0 & 9 & 50 & 0 & 4 & $* *$ \\
\hline Corvlus avellana us & 8 & 8 & 49 & 10 & 1 & $* *$ \\
\hline Acer pseudoplatanus us & 3 & 6 & 48 & 8 & 9 & $* *$ \\
\hline Sambucus racemosa us & 3 & 2 & 48 & 14 & 3 & $* *$ \\
\hline Circaea lutetiana & 8 & 4 & 45 & 0 & 5 & $* *$ \\
\hline Galeopsis tetrahit & 0 & 19 & 44 & 11 & 17 & $* *$ \\
\hline Rubus idaeus us & 0 & 0 & 43 & 7 & 3 & $* *$ \\
\hline Lysimachia nemorum & 0 & 5 & 43 & 0 & 1 & $* *$ \\
\hline Sambucus nigra us & 0 & 12 & 42 & 0 & 2 & $* *$ \\
\hline Urtica dioica & 3 & 0 & 42 & 0 & 4 & $* *$ \\
\hline Rubus idaeus $H$ & 0 & 0 & 38 & 17 & 5 & $* *$ \\
\hline Scrophularia nodosa & 0 & 0 & 38 & 0 & 4 & $* *$ \\
\hline Adoxa moschatellina & 14 & 0 & 35 & 0 & 0 & $* *$ \\
\hline Populus tremula us & 0 & 1 & 33 & 0 & 0 & $* *$ \\
\hline Juncus conglomeratus & 0 & 0 & 33 & 4 & 2 & $* *$ \\
\hline Carex pallescens & 0 & 1 & 32 & 2 & 5 & $* *$ \\
\hline Sambucus racemosa $H$ & 12 & 10 & 31 & 5 & 7 & $* *$ \\
\hline Moehringia trinervia & 0 & 4 & 30 & 7 & 8 & $* *$ \\
\hline Poa trivialis & 15 & 11 & 30 & 1 & 11 & $* *$ \\
\hline Corylus avellana $H$ & 5 & 7 & 29 & 5 & 1 & $* *$ \\
\hline Epilobium angustifolium & 0 & 0 & 28 & 0 & 3 & $* *$ \\
\hline Crataegus monogyna $H$ & 1 & 10 & 27 & 0 & 0 & $* *$ \\
\hline Senecio ovatus & 4 & 7 & 27 & 10 & 18 & * \\
\hline Stachys sylvatica & 9 & 0 & 25 & 0 & 1 & $* *$ \\
\hline
\end{tabular}


Table I. Continued.

\begin{tabular}{|c|c|c|c|c|c|c|}
\hline & Aging CWS & Mature CWS & Postlogged CWS & Enclosed SC & Exclosed SC & $p$ \\
\hline Number of stands & 10 & 25 & 10 & 20 & 50 & \\
\hline $\begin{array}{l}\text { Geum urbanum } \\
\text { Hypericum maculatum agg. } \\
\text { Taraxacum sp. } \\
\text { Sambucus nigra H } \\
\text { Prunus avium H } \\
\text { Stellaria media } \\
\text { Galium aparine } \\
\text { Carex pilulifera }\end{array}$ & $\begin{array}{l}6 \\
0 \\
2 \\
1 \\
9 \\
0 \\
0 \\
0\end{array}$ & $\begin{array}{l}0 \\
0 \\
0 \\
5 \\
4 \\
1 \\
0 \\
1\end{array}$ & $\begin{array}{l}24 \\
24 \\
23 \\
21 \\
17 \\
17 \\
16 \\
13\end{array}$ & $\begin{array}{l}0 \\
0 \\
0 \\
0 \\
0 \\
0 \\
0 \\
0\end{array}$ & $\begin{array}{l}1 \\
2 \\
0 \\
1 \\
0 \\
0 \\
4 \\
1\end{array}$ & $\begin{array}{l}* * \\
* * \\
* * \\
* \\
* \\
* \\
* \\
*\end{array}$ \\
\hline $\begin{array}{l}\text { Rubus fruticosus agg. us } \\
\text { Sambucus racemosa s } \\
\text { Quercus robur } H\end{array}$ & $\begin{array}{l}8 \\
0 \\
0\end{array}$ & $\begin{array}{c}14 \\
1 \\
2\end{array}$ & $\begin{array}{l}29 \\
20 \\
22 \\
\end{array}$ & $\begin{array}{l}26 \\
22 \\
28\end{array}$ & $\begin{array}{c}19 \\
4 \\
26\end{array}$ & $\begin{array}{l}* * \\
* \\
*\end{array}$ \\
\hline $\begin{array}{l}\text { Milium effusum } \\
\text { Dryopteris filix-mas } \\
\text { Carex remota } \\
\text { Dryopteris dilatata } \\
\text { Athyrium filix-femina } \\
\text { Acer pseudoplatanus } s \\
\text { Alnus glutinosa s } \\
\text { Betula alba s } \\
\text { Betula pendula s } \\
\text { Betula pendula A } \\
\text { Populus tremula s }\end{array}$ & & $\begin{array}{c}2 \\
15 \\
0 \\
15 \\
39 \\
28 \\
0 \\
0 \\
0 \\
0 \\
0\end{array}$ & & & & $\begin{array}{l}* * \\
* * \\
* * \\
* * \\
* * \\
* * \\
* * \\
* * \\
* \\
* \\
*\end{array}$ \\
\hline $\begin{array}{l}\text { Quercus robur s } \\
\text { Holcus mollis } \\
\text { Quercus robur us } \\
\text { Polygonum hydropiper }\end{array}$ & $\begin{array}{l}0 \\
0 \\
0 \\
0\end{array}$ & $\begin{array}{l}1 \\
2 \\
0 \\
0\end{array}$ & $\begin{array}{c}0 \\
17 \\
2 \\
0\end{array}$ & $\begin{array}{l}44 \\
34 \\
24 \\
15 \\
\end{array}$ & $\begin{array}{c}0 \\
13 \\
2 \\
2\end{array}$ & $\begin{array}{c}* * \\
* \\
* * \\
*\end{array}$ \\
\hline Glechoma hederacea & 17 & 0 & 1 & 1 & 25 & $*$ \\
\hline $\begin{array}{l}\text { Acer pseudoplatanus A } \\
\text { Alnus glutinosa A } \\
\text { Populus sp. cv. A } \\
\text { Populus tremula A } \\
\text { Quercus robur A } \\
\text { Prunus avium s } \\
\text { Fagus sylvaticas } \\
\text { Fraxinus excelsior s } \\
\text { rubus fruticosus s } \\
\text { Sambucus nigra s } \\
\text { Alnus glutinosa us } \\
\text { Betula alba us } \\
\text { Carpinus betulus us } \\
\text { Crataegus monogyna us } \\
\text { Fagus sylvatica us } \\
\text { Fraxinus excelsior us } \\
\text { Acer pseudoplatanus } H \\
\text { Agrostis canina } \\
\text { Betula alba H } \\
\text { Carex pendula } \\
\text { Deschampsia cespitosa } \\
\text { Digitalis purpurea } \\
\text { Dryopteris affinis subsp. borreri } \\
\text { Dryopteris carthusiana } \\
\text { Fagus sylvatica H } \\
\text { Festuca gigantea } \\
\text { Impatiens noli-tangere } \\
\text { Luzula multiflora } \\
\text { Luzula pilosa } \\
\text { Populus tremula H } \\
\text { Ranunculus repens } \\
\text { Rubus fruticosus agg. H } \\
\text { Stellaria alsine }\end{array}$ & $\begin{array}{c}17 \\
9 \\
0 \\
7 \\
12 \\
0 \\
3 \\
1 \\
2 \\
5 \\
0 \\
0 \\
2 \\
0 \\
0 \\
18 \\
11 \\
0 \\
0 \\
0 \\
36 \\
0 \\
7 \\
17 \\
0 \\
0 \\
0 \\
0 \\
0 \\
0 \\
0 \\
14 \\
0\end{array}$ & $\begin{array}{c}20 \\
16 \\
5 \\
7 \\
12 \\
0 \\
2 \\
2 \\
0 \\
3 \\
0 \\
3 \\
10 \\
0 \\
1 \\
3 \\
22 \\
1 \\
7 \\
0 \\
8 \\
1 \\
0 \\
20 \\
0 \\
0 \\
0 \\
3 \\
0 \\
7 \\
2 \\
21 \\
0\end{array}$ & $\begin{array}{c}21 \\
11 \\
0 \\
1 \\
7 \\
0 \\
0 \\
6 \\
14 \\
12 \\
10 \\
0 \\
17 \\
13 \\
0 \\
4 \\
27 \\
20 \\
3 \\
0 \\
12 \\
0 \\
0 \\
19 \\
3 \\
4 \\
0 \\
8 \\
0 \\
14 \\
11 \\
24 \\
4\end{array}$ & $\begin{array}{c}21 \\
26 \\
0 \\
9 \\
6 \\
0 \\
3 \\
1 \\
2 \\
0 \\
3 \\
5 \\
15 \\
3 \\
2 \\
2 \\
19 \\
3 \\
1 \\
0 \\
12 \\
2 \\
8 \\
22 \\
1 \\
4 \\
0 \\
0 \\
5 \\
6 \\
0 \\
19 \\
4\end{array}$ & $\begin{array}{c}20 \\
18 \\
2 \\
2 \\
12 \\
10 \\
1 \\
7 \\
3 \\
2 \\
3 \\
1 \\
5 \\
0 \\
2 \\
0 \\
20 \\
11 \\
1 \\
10 \\
18 \\
2 \\
3 \\
20 \\
6 \\
1 \\
12 \\
5 \\
5 \\
3 \\
3 \\
21 \\
1\end{array}$ & $\begin{array}{l}\text { ns } \\
\text { ns } \\
\text { ns } \\
\text { ns } \\
\text { ns } \\
\text { ns } \\
\text { ns } \\
\text { ns } \\
\text { ns } \\
\text { ns } \\
\text { ns } \\
\text { ns } \\
\text { ns } \\
\text { ns } \\
\text { ns } \\
\text { ns } \\
\text { ns } \\
\text { ns } \\
\text { ns } \\
\text { ns } \\
\text { ns } \\
\text { ns } \\
\text { ns } \\
\text { ns } \\
\text { ns } \\
\text { ns } \\
\text { ns } \\
\text { ns } \\
\text { ns } \\
\text { ns } \\
\text { ns } \\
\text { ns } \\
\text { ns }\end{array}$ \\
\hline
\end{tabular}

Woody species are shown in different vegetation layers: $A$ : arborescent stratum, $s$ : shrubby stratum, $u s$ : undershrubby stratum, $H$ : herbaceous stratum. Monte Carlo test of significance of observed maximum indicator value: ns: non significant, $* 0.05<p \leq 0.01, * * 0.01<p \leq 0.001, * * * p<0.001$. 
Within the SC group, we found only weak differences between enclosed and exclosed stands, except young individuals of Quercus robur which were restricted to enclosed SC stands.

Results of DCA are shown in Figure 2. The reliability of the main gradient structure identified by DCA and NMS was confirmed by high pairwise rank correlations between the first three axes of the DCA and NMS ordinations (DCA1 and NMS1: $\rho=0.775, p<0.0001 ;$ DCA2 and NMS3: $\rho=0.915$, $p<0.0001$; DCA3 and NMS2: $\rho=-0.408, p<0.0001)$. The eigenvalues of the first three DCA ordination axes were 0.184 , 0.091 and 0.061 , respectively. Total inertia in the species data reached 1.449. Axis 1 provided a very good separation between the two silvicultural systems: CWS stands showed the highest scores, while SC stands corresponded to the lowest values (Fig. 2a). We found a significant correlation between relevé scores along this axis and Ellenberg indicator values for soil moisture, soil reaction, soil nutrient and continentality (Tab. II). All these indicator values were significantly correlated. This indicates that plant communities from CWS stands were less hygrophilic but more neutrophilous and eutrophic than those from SC stands. This axis also provided a clear gradient from postlogged CWS stands up to aging CWS stands, through mature CWS stands.

Axis 2 did not provide a clear segregation of the two treatments. The lowest scores mainly corresponded to mature CWS stands and enclosed SC stands, while the highest scores were obtained for postlogged CWS stands and some exclosed SC stands. This axis correlated significantly with Ellenberg indicator values for light, as well as with tree and shrub cover, suggesting a gradient of increasing light availability. It is noteworthy that $\mathrm{SC}$ stands were much more sparsely distributed in the factorial plan defined by the first two axes than CWS stands. This indicates a greater heterogeneity of environmental conditions among stands submitted to SC compared to those under CWS treatment.

Axis 3 (Fig. 2b) provided the weakest congruency between DCA and NMS. Its ecological significance was unclear. Whatever the subgroup of CWS stands considered, the relevés were sparsely distributed all along the gradient. Thus, it did not significantly influence vegetation patterns. For SC, enclosed stands tended to group toward the highest values, while lower scores rather corresponded to exclosed stands. This axis correlated negatively with tree cover but positively with shrub cover. As it also poorly correlated with Ellenberg indicator value for light, we suspect an effect of ungulate predation.

\section{DISCUSSION}

\subsection{Plant community composition as a function of silviculture}

We found significant differences in vegetation composition among forest stands, even over similar climatic, topographic and edaphic conditions and within the same local pool of species. CWS and SC stands strongly differed by their vegetation composition, although all the included stands were located into the same forest, which has been managed as CWS for many centuries, until the end of the 1970s. Thus, CWS may be considered as the "normal" disturbance regime of the forest studied, which has patterned vegetation and controlled forest dynamics. Conversion of former CWS stands into SC stands represents a shift in this disturbance regime. Although this shift was very recent at the scale of forest dynamics ( 20 years), our results clearly suggest that it has already caused important changes in plant species composition and relative abundance.

First, most species associated with CWS are usually considered as true forest species, including vernal geophytes (e.g. Hyacinthoides non-scripta, Ranunculus ficaria, Polygonatum multiflorum) and "ancient forest species" sensu Hermy et al. [37] (e.g. Lamium galeobdolon, Oxalis acetosella). Vernal geophytes are often considered as coppicing-associated species $[33,56]$. Conversely, species associated to SC were rather edge or even meadow species, and ferns. An increase in the cover of graminoids and ferns after thinning has often been reported $[31,54,63,66]$, even in selective-cutting systems $[4,70]$. Here, the high frequency of thinnings allows to these species to maintain since a high proportion of solar radiation permanently reaches the forest floor.

Second, in the CWS system, we found strong floristic differences between the three subgroups, suggesting a clear shift in species composition along the silvicultural cycle. This is in full accordance with previous studies dealing with forest succession along the coppice cycle [2]. Postlogged CWS stands supported a very original species assemblage, mainly composed of clearing species or shade-tolerant ruderals. This is consistent with many studies which have shown that post-harvesting communities were species-rich and contain species adapted to very contrasted disturbance regimes (i.e. "generalists") [2, 29, 62]. Coppicing represents a major disturbance in this silvicultural system, which results in an increase of species diversity, by lowering the dominance of a few species, thereby freeing resources for early successional species and by increasing environmental heterogeneity [21, 34, 67].

Mature CWS stands supported a lower species richness than postlogged stands, since tree canopy-shade has excluded almost all open-habitat species while several perennials have become dominant. Those are either vernal geophytes, like Hyacinthoides non-scripta for example, which develop a "shade evading" strategy [19, 56], or wintergreen chamaephytes, like Lamium galeobdolon for example, which exhibit a "shade-tolerating" strategy [19].

We also found a group of 8 species which was almost restricted to the oldest CWS stands, which have escaped the normal sivicultural cycle. Some of them are often considered as "ancient forest species" [37]. These species may not recover quickly once extirpated because of altered environmental conditions, lack of seed banks or slow dispersion [36, 49]. The other characteristic species of aging CWS stands are rather species of moist soils. Their presence may be related to forest microclimate, directly influenced by stand structure. It is well known that a closed canopy induces a high hygrometry at the level of the understories, by reducing evapotranspiration [14]. This may thus promote non-forest hygrophilous species which are sufficiently shade-tolerant. 

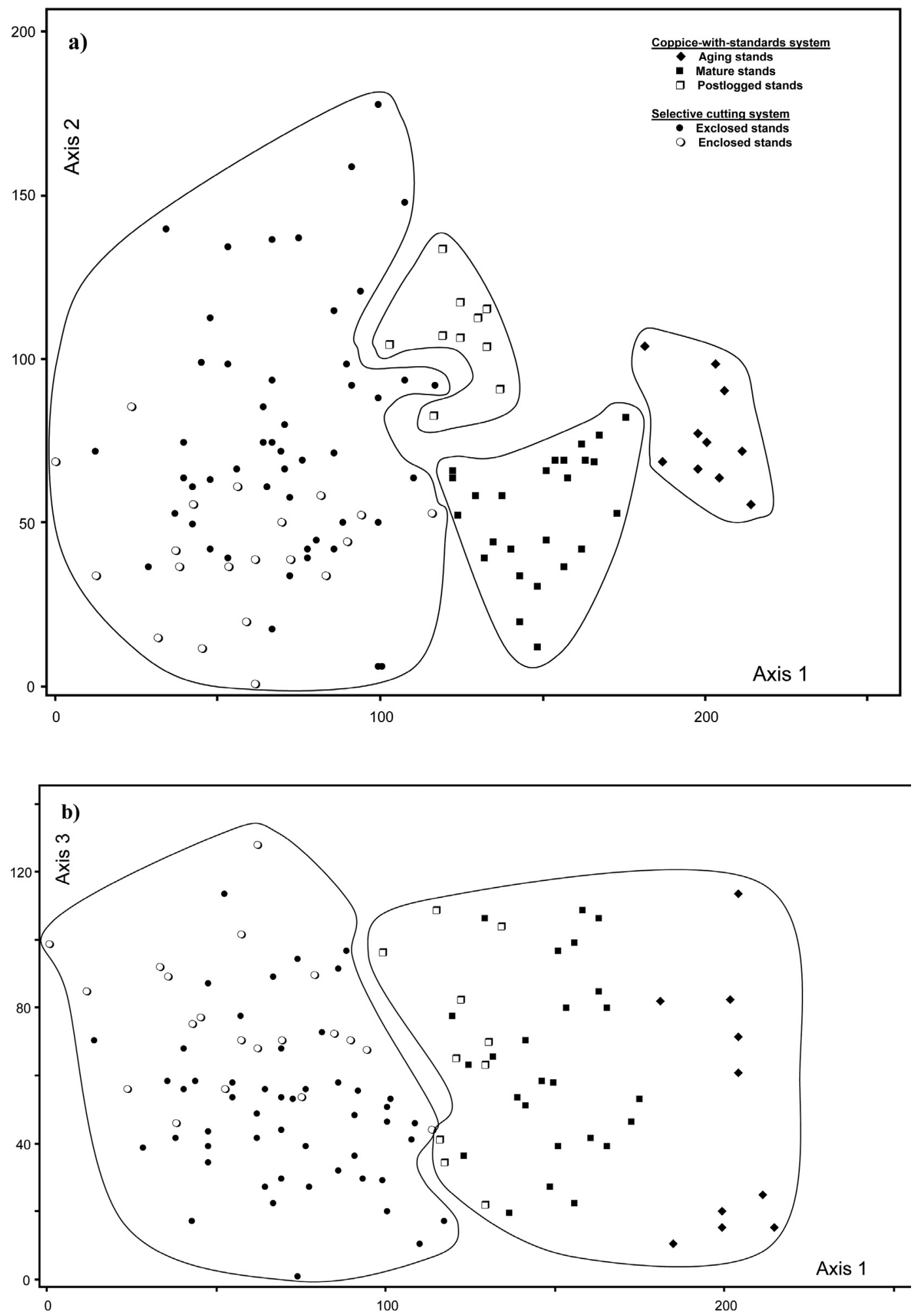

Figure 2. Diagrams provided by the Detrended correspondence analysis of the relevés. (a) Diagram defined by axes 1 and 2; (b) diagram defined by axes 1 and 3 . 
Table II. Spearman rank correlations between "relevé" scores on DCA axes and mean Ellenberg indicator/woody vegetation cover values, and between Ellenberg indicator values themselves.

\begin{tabular}{lcccccccc}
\hline & Axis 1 & Axis 2 & Axis 3 & $\mathrm{L}$ & $\mathrm{F}$ & $\mathrm{R}$ & $\mathrm{N}$ \\
\hline $\mathrm{L}$ & $-0.343^{* * *}$ & $0.388^{* * * *}$ & $0.191^{*}$ & - & $0.411^{* * * *}$ & $-0.275^{* *}$ & $\mathrm{~ns}$ & $0.240^{*}$ \\
$\mathrm{~F}$ & $-0.581^{* * * *}$ & $\mathrm{~ns}$ & $\mathrm{~ns}$ & $0.411^{* * * *}$ & - & $-0.531^{* * * *}$ & $-0.456^{* * * *}$ & 0.340 \\
$\mathrm{R}$ & $0.796^{* * * *}$ & $0.340^{* * *}$ & $\mathrm{~ns}$ & $-0.275^{* *}$ & $-0.531^{* * * *}$ & - & $0.742^{* * * *}$ & $0.221^{*}$ \\
$\mathrm{~N}$ & $0.479^{* * * *}$ & $0.455^{* * * *}$ & $\mathrm{~ns}$ & $\mathrm{~ns}$ & $-0.456^{* * * *}$ & $0.742^{* * * *}$ & - & $\mathrm{ns}$ \\
$\mathrm{K}$ & $-0.388^{* * * *}$ & $\mathrm{~ns}$ & $\mathrm{~ns}$ & $0.240^{*}$ & 0.340 & $0.221^{*}$ & $\mathrm{~ns}$ & - \\
$\mathrm{R} \% \mathrm{~A}$ & $0.227^{*}$ & $-0.353^{* * *}$ & $-0.403^{* * * *}$ & $-0.216^{*}$ & $-0.319^{* * *}$ & $\mathrm{~ns}$ & $\mathrm{~ns}$ & $\mathrm{~ns}$ \\
$\mathrm{R} \% \mathrm{~s}$ & $0.186^{*}$ & $-0.284^{* *}$ & $0.409^{* * * *}$ & $\mathrm{~ns}$ & $\mathrm{~ns}$ & $\mathrm{~ns}$ & $\mathrm{~ns}$ & $-0.193^{*}$ \\
$\mathrm{R} \% \mathrm{~A}+\mathrm{s}$ & $0.329^{* * *}$ & $-0.391^{* * * *}$ & $\mathrm{~ns}$ & $-0.226^{*}$ & $-0.307^{* *}$ & $\mathrm{~ns}$ & $\mathrm{~ns}$ & $\mathrm{~ns}$ \\
\hline
\end{tabular}

Ellenberg's indicator values. L: light, F: soil moisture, R: soil reaction, N: soil nutrient, K: continentality.

$\mathrm{R} \%$ : total cover of the arborescent stratum (A), shrubby stratum (s) and both arborescent and shrubby strata (A+s).

Significance of the Spearman rank correlation test: ns: non significant, $* 0.05<p \leq 0.01, * * 0.01<p \leq 0.001, * * * 0.001<p \leq 0.0001, * * * * p<0.0001$.

\subsection{Coincidence with environmental factors}

Our results have shown distinct vegetation patterns, which may be related to contrasted silviculture-associated environmental conditions. As we did not perform any direct measure of environmental factors, we used the Ellenberg's system, which has proved its efficiency in providing accurate estimations $[26,52,65]$. By analysing the coincidence of effects on composition and ecological factors, we may thus understand the response of vegetation to silviculture.

The number of significant correlations between DCA axis 1 and Ellenberg indicator values showed that this axis may be interpretated as a complex environmental gradient. As this axis was the one providing the best separation between the two silvicultural systems and between the three sub-groups of CWS stands, we conclude that silviculture clearly modulates a host of ecological factors.

Firstly, indicator value for soil moisture was found to be significantly higher for SC than for CWS stands. This may be related to thinning intensity since soil moisture directly depends on both the level of the water table and the proportion of throughfall precipitation reaching the forest floor. On average, canopy opening is rather higher and tree density lower in SC than in CWS stands, that leads to highest field capacity. Moreover, tree harvesting and thinnings are performed by use of heavy vehicles, that results in soil compaction and modifies local drainage conditions. As there is no permanent extraction trails in SC stands, soil compaction occurs throughout the stands. Both stand structure and log-extraction practices may thus explain the higher proportion of hygrophilous species in SC stands, like Carex pendula, Carex remota, Alnus glutinosa, etc.

Secondly, we found that axis 1 also corresponded to a gradient of increasing soil reaction and nutrient. According to Ellenberg et al. [25], soil reaction and soil nutrient are mainly determined by $\mathrm{pH}$ and nitrogen content respectively, so that the combination of these two values gives an estimation of soil fertility. Our results clearly suggest that CWS is associated to more fertile soils, compared to SC. As both substrate and soil profile were assumed to be uniform over the whole area sampled, the difference observed may be interpretated as an indirect composite effect of silviculture. It has long been accepted that silviculture modifies soil properties [42, 64]. As both soil reaction and soil nutrient were negatively correlated with soil moisture, we may relate the differences in soil fertility to those of the water table level. Given the substrate (loess) and the relief (plateau), the thinning-induced rise of the water table level may both decrease $\mathrm{pH}$ and increase ferrous (iron II) ions in the upper soil horizons [22, 43, 44, 56]. It is also well-known that thinning can cause nutrient losses by means of stream and ground water $[8,44]$. Another mechanism would be the direct feedback of vegetation composition on soil properties, particularly at the humus layer level. Tree species were much more diversified into CWS stands than in SC stands. Most of woody species characterising CWS stands (e.g. Carpinus betulus, Fraxinus excelsior, Salix caprea, Corylus avellana) are well-known as providing a litter with a low C:N ratio. Conversely, in SC stands the proportion of Quercus robur and Fagus sylvatica was higher, and thus acidification of the upper soil horizons may be enhanced.

Thirdly, we found that axis 1 was also correlated with Ellenberg indicator value for continentality. In Ellenberg's system, continentality indicates the difference in temperature during the course of the day and of the year, and the air humidity. A low value indicates an oceanic climate (i.e. high hygrometry and low thermic variations) while a high value indicates a continental climate (i.e. low hygrometry and large thermic variations) $[25,41]$. Of course this indicator value makes sense at broad geographical scale. Here we have tested it at a local scale and we found significant variations. Thus we consider that at a local scale it may be a good estimator of forest microclimate, the latter being defined by relative humidity and air temperature. Our results clearly suggest that axis 1 corresponded to a gradient of decreasing continentality, that means that forest microclimate is better conserved in CWS than in SC stands (i.e. higher hygrometry and lower thermic variations). This result is consistent with previous studies which found that forest structure, particularly canopy opening, was a good surrogate for the degree of forest microclimate $[1,13,14,61]$. In SC stands, the scarcity of true forest species, which are often sciaphytes capable of growing as facultative semi-heliophytes [56], may be explained by the fact that microclimate is permanently 
altered. These species are competitively excluded by heliophilous ruderals, particularly Rubus fruticosus [15, 66]. These results emphasize the importance of microclimate in forest ecosystem and its role in influencing vegetation patterns [14].

DCA axes 2 and 3 did not clearly separate the two silvicultural treatments. Both provided a quite good separation between enclosed and exclosed SC stands. Axis 2 also indicated a gradient from mature to postlogged, through aging CWS stands. The positive correlation between DCA axis 2 and Ellenberg indicator value for light suggests a gradient of increasing light availability. This seems to be confirmed by the significant decrease of both tree and shrub cover along this axis. Within the CWS group, postlogged stands supported the highest values and mature stands the lowest ones. Aging stands tended to occupy an intermediary position, probably because of the occurrence of self-thinning processes: light-demanding tree species, like Salix caprea, Populus tremula or Alnus glutinosa, progressively die, inducing canopy gaps and thus light penetration in the understories. Conversely, in SC stands light is permanently patchily distributed at the ground level so that lightdemanding species are able to persist and regenerate. It should be noted therefore that enclosed SC stands provided lower values for light than exclosed SC stands. We hypothesize a difference in ungulate predation. Indeed, our results show that young trees (particularly Quercus robur) and shrubs were more frequent and abundant in enclosed SC stands compared to exclosed stands, that may decrease solar radiation at the forest floor level. The distribution of SC stands along axis 3, the negative correlation with tree cover but positive with shrub cover also suggest an effect of game predation. It is known that forest structure can markedly influence the attractiveness for herbivore ungulates which in turn strongly affect vegetation structure and plant composition [60]. For example, clear-cut systems are known to be very attractive for roe deer and thus, predispose the forest to strong game damage $[28,60]$. Our results suggest that $\mathrm{SC}$ would produce forest stands more attractive for roe deer than CWS and thus induce a stronger game influence on plant composition. The scarcity of woody saplings as well as the abundance of graminoid species in exclosed SC stands compared to both CWS stands and enclosed SC stands, may be partly explained by differences in roe deer densities. This is consistent with Packham et al. [56] who reported that roe deer can completely eliminate sensitive woodland plants and promote graminoids since they lack the ciliated protozoa associated with the ability to digest grasses found in cervids.

\subsection{Management implications}

The observed differences mainly concern understory species, particularly herbs and woody saplings. This is of major concern within the framework of sustainable forestry since (1) the major part of plant diversity in temperate forest ecosystems is supported by the understories $[17,35,72]$ and (2) woody saplings indicate which species are able to spontaneously regenerate and thus, what would be the forest of the future.

As stressed above, true forest species (i.e. specialists) were mainly found in mature and aging CWS stands, while SC stands and postlogged CWS stands were rather characterized by heliophilous ruderals (i.e. generalists). This may be explained by the length of the harvesting rotation, which defines the distur- bance regime of the forest ecosystem. In CWS, the 30-years rotation allows true forest species to recover between two harvests. Nevertheless, our results show that only the herb layer supported late-successional species, i.e. herbaceous dryads sensu Decocq and Hermy [19], like Anemone nemorosa, Hyacinthoides non-scripta, Paris quadrifolia, etc. This suggests that the length of the current silvicultural cycle does not allow woody late-successional species (e.g. Fagus sylvatica, Ilex aquifolium in the study area, see [16]) to establish. In SC, wood extraction occurs every 4 years, so that the ecosystem may be considered as permanently disturbed, that prevents forest from maturation. Thus, true forest species are not able to recover or even to maintain, probably because they are competitively excluded by aggressive light-demanding ruderals, like Rubus fruticosus agg. for example. This is a phenomenon which has been reported already for other silvicultural systems [23]. This result also leads to question about what "ancient forest species", or even "true forest species", are. As many European forests have been managed according to a traditional system close to CWS often since the Roman times, CWS management is also part of the evolutionary history of ecosystems and as such should be regarded as part of normal forest function rather than an external disturbance [20]. Maybe the so-called "ancient forest species" may be better labelled "coppice-woodland species", as some authors have done in the past $[2,56]$. Within the framework of European temperate forests, coppicing is therefore an important trait of forest history and thus may have pattern ancient forest biodiversity. Anyway, we conclude that it is essential to retain cores of old coppice woods within managed forests to conserve remnants of the original shade flora. Oldgrowth forest stands accompanying shortened harvest rotations may be a more suitable strategy for a sustainable forest management [53].

Another important result concerns biodiversity at a the landscape scale. We found very contrasted species assemblages among the three subgroups of CWS stands assessed, indicating an overall high plant community diversity at the scale of the forest landscape. It is well documented that within a particular wood, different stages of a coppicing cycle provide a wide variety of structural and climatic conditions, so that the wood as a whole supports a high diversity of species $[11,56]$. This supports the general model of vegetation development of secondary succession formulated by Bormann and Likens [8] and also described in even-aged highforests [3]. Conversely, plant species composition was quite constant among SC stands, suggesting a more homogeneous forest vegetation. This result must be directly related to the silvicultural system. By mimicking the natural gap dynamics (e.g. treefalls), SC favours small-scale heterogeneity, but tree-by-tree harvesting is applied equally and simultaneously to all stands, so that the forest as a whole is more homogeneous. As forest management has been recognized as the main control on plant community diversity at the landscape scale [18], we confirm the conclusions of previous studies which have shown that "close-to-nature" silviculture reduced beta-diversity among stands and thus forest heterogeneity at the scale of the whole forest $[6,12,59]$.

Results of the ISA indicate contrasted response of tree saplings to the silvicultural system. Some species, like Sorbus aucuparia and Carpinus betulus for example, were linked to CWS, while others, like Acer pseudoplatanus and Betula spp. 
for example, were rather associated to SC. Among commercial species, it should be noted that saplings of Quercus robur were exclusively found into enclosed SC stands, suggesting that they undergo strong game damages. Other economically interesting species, like Fagus sylvatica, Fraxinus excelsior or Prunus avium were not significantly differently distributed among treatments and were often constant in the understories, whatever the silvicultural system. We conclude that silviculture seems to poorly influence forest regeneration, but we cannot exclude the hypothesis of a progressive shift in the relative abundance of species following the conversion of former CWS stands into SC stands.

Finally, our results suggest some indirect effects of silviculture on plant species composition, like attractiveness for roe deer, soil compaction and water table level oscillations, which require further investigations. Influence of habitat conditions should also be assessed, as well as comparison with other silvicultural systems, like even-aged clearcut system for example.

Acknowledgements: This work was possible thanks to the French Office national des Forêts (Hirson division, Philippe Goupil) and the Compagnie forestière du Nouvion (François Barisien) which have helped us in the site selection. We thank Régis Courtecuisse for assistance on the field, and Arnault Lalanne for measures of forest structure. We also acknowledge the two anonymous referees for their helpful comments on the initial draft. This study was founded by the GIP ECOFOR ("Biodiversité et gestion forestière" program).

\section{REFERENCES}

[1] Anderson R.C., Loucks O.L., Swain A.M., Herbaceous response to canopy cover, light intensity and throughfall precipitation in coniferous forests, Ecology 50 (1969) 255-263.

[2] Ash B.E, Barkham J.P., Changes and variability in the field layer of a coppiced woodland in Norfolk, England. J. Ecol. 64 (1976) $697-$ 712.

[3] Aubert M., Alard D., Bureau F., Diversity of plant assemblages in managed temperate forests: a case study in Normandy (France), For. Ecol. Manage. 175 (2003) 321-337.

[4] Aude E., Lawesson J.E., Vegetation in Danish beech forests: the importance of soil, microclimate and management factors, evaluated by variation partitioning, Plant Ecol. 134 (1998) 53-65.

[5] Becker M., Influence du traitement sylvicole sur la flore forestière: cas de la futaie et du taillis-sous-futaie, Vegetatio 40 (1979) 155161.

[6] Beese W.J., Bryant A.A., Effect of alternative silvicultural systems on vegetation and bird communities in coastal montane forests of British Columbia, Canada, For. Ecol. Manage. 115 (1999) 231242.

[7] Begon M., Harper J.L., Towsend C.R., Ecology: Individuals, populations and communities, 3rd ed., Blackwell Science, Oxford, 1996.

[8] Bormann F.H., Likens G.E., Pattern and process in forested ecosystem, Springer-Verlag, New York, 1979.

[9] Braun-Blanquet J., Pflanzensoziologie Grünzüge der Vegetationsgrunde, Springer, Berlin, 1964.

[10] Brown J.H., Two decades of homage to Santa Rosalia: toward a general theory of diversity, Am. Zool. 21 (1981) 877-888.

[11] Buckley G.P., Ecology and management of coppice woodlands, Chapman and Hall, London, 1992.
[12] Carleton T.J., Vegetation responses to the managed forest landscape of central and northern Ontario, in: Perera A.H., Euler D.L., Thompson I. (Eds.), Ecology of a managed terrestrial landscape, University of British Columbia Press, Vancouver, 2000, pp. 178197.

[13] Chen J., Franklin J.F., Growing-season microclimate variability within an old-growth Douglas-fir forest, Climate Res. 8 (1997) 21-34.

[14] Chen J., Saunders S.C., Crow T.R., Naiman R.J., Brosofske K.D. Mroz G.D., Brookshire B.L., Franklin J.F., Microclimate in forest ecosystem and landscape ecology, Bioscience 49 (1999) 288-297.

[15] Collins B.S., Dunne D.P., Pickett S.T.A., Responses of forest herbs to canopy gaps, in: Pickett S.T.A., White P.S. (Eds.), The ecology of natural disturbance and patch dynamics, Academic Press, Orlando, 1985, pp. 218-234.

[16] Decocq G., Données phytosociologiques récentes sur les forêts de la Thiérache (Aisne, France). I. Les forêts mésophiles de la Thiérache argilo-calcaire, Acta Bot. Gallica 145 (1998) 125-147.

[17] Decocq G., The "masking effect" of silviculture on substrate-induced plant diversity in oak-hornbeam forests from northern France, Biodiv. Conserv. 9 (2000) 1467-1491.

[18] Decocq G., Patterns of plant species and community diversity at different organization levels in a forested riparian landscape, $\mathrm{J}$ Veg. Sci. 13 (2002) 91-106.

[19] Decocq G., Hermy M., Are there herbaceous dryads in temperate deciduous forests? Acta Bot. Gallica 150 (2003) 373-382.

[20] Decocq G., Aubert M., Dupont F., Alard D., Saguez R., WattezFranger A., de Foucault B., Delelis-Dusollier A., Bardat J., Plant diversity in a managed temperate deciduous forest: understorey response to two silvicultural systems, J. Appl. Ecol. 41 (2004) 10651079.

[21] Denslow J.S., Patterns of plant species diversity during succession under different disturbance regimes, Oecologia 46 (1980) 18-21.

[22] Duchaufour P., Pédologie : sol, végétation, environnement, Masson, Paris, 1995.

[23] Duffy D.C., Meier A.J., Do Appalachian herbaceous understories ever recover from clearcutting? Conserv. Biol. 6 (1992) 196-201.

[24] Dufrêne M., Legendre P., Species assemblages and indicator species: the need for a flexible asymmetrical approach, Ecol. Monogr. 67 (1997) 53-73

[25] Ellenberg H., Weber H.E., Düll R., Wirth V., Werner W., Paulissen D., Zeigerwerte der Gefäßpflanzen (ohne Rubus), Scripta Geobot. 18 (1991) 9-166.

[26] Ertsen A.C.D., Alkemade J.R.M., Wassen M.J., Calibrating Ellenberg indicator values for moisture, acidity, nutrient availability and salinity in the Netherlands, Plant Ecol. 135 (1998) 113-124.

[27] Franklin J.F., Towards a new forestry, Am. Forest. 95 (1989) $37-$ 44.

[28] Gill R.M.A., A review of damage by mammals in north temperate forests: 1. Deer, Forestry 65 (1992) 145-169.

[29] Gilliam F.S., Roberts M.R., Plant diversity in managed forests, Ecol. Appl. 5 (1995) 911-912.

[30] Gillis A.M., The new forestry, Bioscience 40 (1990) 558-562.

[31] Griffis K.L., Crawford J.A., Wagner M.R., Moir, W.H., Understory response to management treatments in northern Arizona ponderosa pine forests, For. Ecol. Manage. 146 (2001) 239-245.

[32] Grime J.P., Plant strategies and vegetation processes, John Wiley \& Sons, London, 1979

[33] Grime J.P., Hodgson J.G., Hunt R. Comparative plant ecology, a functionnal approach to common British species, Unwin Hyman Ltd, London, 1988. 
[34] Grubb P.J., The maintenance of species richness in plant communities: the importance of the regeneration niche, Biol. Rev. 52 (1977) 107-145.

[35] Halpern, C.B., Spies, T.A., Plant species diversity in natural and managed forests of the Pacific Northwest, Ecol. Appl. 5 (1995) 913-934.

[36] Hannerz M., Hannell B. Effects on the flora in Norway spruce forests following clearcutting and shelterwood cutting, For. Ecol. Manage. 90 (1997) 29-49.

[37] Hermy M., Honnay O., Firbank L., Grashof-Bokdam C., Lawesson J.E., An ecological comparison between ancient and other forest plant species of Europe, and the implications for forest conservation, Biol. Conserv. 91 (1999) 9-22.

[38] Huston M., A general hypothesis of species diversity, Am. Nat. 104 (1979) 501-528.

[39] Kirby K.J., Watkins C., The ecological history of European forests, CAB International, Oxon, 1998.

[40] Lambinon J., De Langhe J.E., Delvosalle L., Duvigneaud J., 1992. Nouvelle flore de la Belgique, du Grand-Duché de Luxembourg, du Nord de la France et des régions voisines, $4^{\mathrm{e}}$ ed., Éditions du Patrimoine du Jardin botanique national de Belgique, Meise.

[41] Landolt E., Ökologische Zeigerwerte zur Schweizer Flora, Veröffentlichungen des Geobotanischen Institutes der ETH, Stiftung Rübel, Zürich 64 (1977) 1-208.

[42] Larsen J.B., Ecological stability of forest and sustainable silviculture, For. Ecol. Manage. 73 (1995) 85-96.

[43] Martin M.H, Conditions affecting the distribution of Mercurialis perennis L. in certain Cambridgeshire woodlands, J. Ecol. 56 (1968) 777-793.

[44] Martin C.W., Noel D.S., Federe C.A., Clearcutting and the biochemistry of streamwater in New England, J. Forest. 83 (1985) 686689

[45] McCune B., Grace J.B., Analysis of ecological communities. MjM Software Design, Gleneden Beach, 2002.

[46] McCune B., Mefford M.J., PC-ORD. Multivariate analysis of ecological data, version 4, MjM Software Design, Gleneden Beach, 1999.

[47] McIntyre S., Lavorel S., Trémont R.M., Plant life-history attributes: their relationship to disturbance response in herbaceous vegetation, J. Ecol. 3 (1995) 31-44.

[48] McMinn J.W., Diversity of woody species 10 years after four harvesting treatments in the oak-pine type, Can. J. For. Res. 22 (1992) $128-136$.

[49] Meier A.J., Bratton S.P., Duffy D.C., Possible ecological mechanisms for loss of vernal-herb diversity in logged eastern deciduous forests, Ecol. Appl. 5 (1995) 935-946.

[50] Mielke P.W., Meteorological applications of permutation techniques based on distance functions, in: Krishnaiah P.R., Sen P.K (Eds.), Handbook of statistics 4, Elsevier, London, pp. 813-830.

[51] Mitchell R.J., Palik B.J., Hunter M.L. Natural disturbance as a guide to silviculture, For. Ecol. Manage. 155 (2002) 315-317.

[52] Mountford J.O., Chapman J.M., Water regime requirements of British wetland vegetation: using the moisture classifications of Ellenberg and Londo, J. Environ. Manage. 38 (1993) 275-288.

[53] Nagaike T., Hayashi A., Effects of extending rotation period on plant species diversity in Larix kaempferi plantations in central Japan, Ann. For. Sci. 61 (2004) 197-202.
[54] Naumburg E., DeWald L.E., Relationships between Pinus ponderosa forest structure, light characteristics, and understory graminoid species presence and abundance, For. Ecol. Manage. 124 (1999) 205-215.

[55] Økland R.H., Vegetation ecology: theory, methods and applications with reference to Fennoscandia, Sommerfeltia, Suppl. 1 (1990) 1-233.

[56] Packam J.R., Harding D.J.L., Hilton G.M., Stuttard R.A., Functional ecology of woodlands and forests, Chapman \& Hall, London, 1992.

[57] Picket S.T.A., White, P.S., Natural disturbance and patch dynamics, Academic Press, London, 1985.

[58] Rameau J.C., Mansion D., Dumé G., Timbal J., Lecointe A., Dupont P., Keller R., Flore forestière française. 1. Plaines et collines, Institut pour le Développement Forestier, Paris, 1989.

[59] Reich P.B., Bakken P., Carlson D., Frelich L.E., Friedman S.K., Grigal D.F., Influence of logging, fire, and forest type on biodiversity and productivity in southern boreal forests, Ecology 82 (2001) 2731-2748.

[60] Reimoser F., Gossow H., Impact of ungulates on forest vegetation and its dependence on the silvicultural system, For. Ecol. Manage. 88 (1996) 107-119.

[61] Reifsnyder G.M., Furnival G.M., Horowitz J.L., Spatial and temporal distribution of solar radiation beneath forest canopies, Agric. Meteorol. 9 (1971) 21-37.

[62] Roberts M.R., Gilliam F.S., Patterns and mechanisms of plant diversity in forested ecosystems: implications for forest management, Ecol. Appl. 5 (1995) 969-977.

[63] Roberts M.R., Zhu L., Early response of the herbaceous layer to harvesting in a mixed coniferous-deciduous forest in New Brunswick, Canada, For. Ecol. Manage. 155 (2002) 17-31.

[64] Rubio A., Gavilàn R, Escudero A., Are soil characteristics and understorey composition controlled by forest management? For. Ecol. Manage. 113 (1999) 191-200.

[65] Ter Braak C.J.F., Wiertz J., On the statistical analysis of vegetation change: a wetland affected by water extraction and soil acidification, J. Veg. Sci. 5 (1994) 361-372.

[66] Thomas S.C., Halpern C.B., Falk D.A., Liguori D.A., Austin, K.A., Plant diversity in managed forests: understory responses to thinning and fertilization, Ecol. Appl. 9 (1999) 864-879.

[67] Tilman D., Pacala S.W., The maintenance of species richness in plant communities, in: Ricklefs R.E., Schluter D. (Eds.), Species diversity in ecological communities: historical and geographical perspectives, University of Chicago Press, Chicago, 1993, pp. 1325.

[68] Van der Maarel E., Transformation of cover-abundance values in phytosociology and its effects on community similarity, Vegetatio 39 (1979) 97-144.

[69] Van der Maarel E., Some remarks on disturbance and its relations to diversity and stability, J. Veg. Sci. 3 (1993) 733-736.

[70] Volpers T., Changes in microclimate and vegetation after thinning in a montane virgin forest, Phytocoenologia 17 (1989) 71-104.

[71] Warming E., Skovene, Botanisk Tidsskrift 35 (1919) 1-653.

[72] Whittaker R.H., Dominance and diversity in land plant communities, Science 147 (1965) 250-260. 